\title{
Device Improper Composition/Concentration
}

National Cancer Institute

\section{Source}

National Cancer Institute. Device Improper Composition/Concentration. NCI Thesaurus. Code C92064.

Problems associated with the improper combination of materials or elements present in the device (e.g. improper composition of the materials of a capacitor). 